\title{
Attitudes towards the immigration of students from a nursing school in Portugal
}

Actitudes ante la inmigración del alumnado de una escuela de enfermería de Portugal Atitudes em relação à imigraçáo dos alunos de uma escola de enfermagem de Portugal María Idoia Ugarte Gurrutxaga* (D); Maria Lucília Cardoso** (D); Beatriz Xavier*** (D); Brígida Molina Gallego**** (D); Manuel Alves Rodrigues***** (D)

\begin{abstract}
Background: Cultural diversity is present in all societies. Nurses must be culturally competent to provide quality care. Objective: To validate the Scale of Attitude toward Immigration in Nursing (EAIE) in Portuguese and to know the attitudes toward the immigration of the first-year undergraduate students of a nursing school in Portugal.

Methodology: Descriptive, exploratory, and analytical study, with the translation and transcultural adaptation of the EAIE to the Portuguese language, composed of 39 items. The participants were 143 students.

Results: Scale with a good internal consistency, assessed with Cronbach's $\alpha(0,94)$. With the univariate analysis of the scale and each separate item, significant attitudinal differences were identified between men and women in 6 items, and among age groups in 2 items.

Conclusion: The attitudes of a portion of the students are not favorable to the full recognition of the rights of health and social resources of the immigrants. It is necessary to develop the training in cultural competence and the Universal Right to Health.
\end{abstract}

Keywords: attitude; emigrants and immigrants; cultural diversity; nursing; health

\section{Resumen}

Marco contextual: La diversidad cultural está presente en todas las sociedades. Las enfermeras deben ser culturalmente competentes para dispensar cuidados de calidad. Objetivo: Validar la Escala de Actitud hacia la Inmigración en Enfermería (EAIE) al portugués y conocer las actitudes ante la inmigración del alumnado del primer curso del grado de una escuela de Enfermería de Portugal. Metodología: Estudio descriptivo, exploratorio y analítico, con traducción y adaptación transcultural de la EAIE al portugués, constituida por 39 ítems. Participaron 143 estudiantes.

Resultados: Buena consistencia interna de la escala medida con el $\alpha$ de Cronbach $(0,94)$. Con el análisis unifactorial de la escala, y de cada ítem separado se identificaron diferencias actitudinales significativas entre hombres y mujeres en 6 ítems, y entre grupos de edad en 2 ítems. Conclusión: Las actitudes de una parte del alumnado no son favorables al reconocimiento pleno de los derechos en el uso de los recursos sociosanitarios de los inmigrantes. Consideramos necesario profundizar en la formación en competencia cultural y en el Derecho Universal a la Salud.

Palabras clave: actitud; emigrantes e inmigrantes; diversidad cultural; enfermería; salud

\footnotetext{
* Ph.D., Collaborating Professor, University of Castilla-La Mancha. University College of Nursing and Physiotherapy, 45071, Toledo, Spain [maria.ugarte@uclm.es]. (1) https:// orcid.org/0000-0003-2413-3628. Contribution to the article: substantial contribution to the conception and design of the study, data collection, data interpretation, and writing and critical review of the content. Address for correspondence: Calle Cerro Miraflores 1, 45071, Toledo, España.

*:MSc., Research Fellow, Health Sciences Research Unit: Nursing, Nursing School of Coimbra, 3046-851, Coimbra, Portugal [luciliacardoso77@hotmail.com].Đ https://orcid.org/0000-00029433-7434. Contribution to the article: data statistical treatment and analysis.

***Ph.D., Sociologist. UICISA: E Researcher and Adjunct Professor of the ESEnfC. 3046-851, Coimbra, Portugal [bxavier@ esenfc.pt] Ph.D., D https://orcid.org/0000-0002-1787-4586. Coimbra, Portugal bxavier@esentc.pt Ph.D., 1 https://orcid.org/0000-1
Contribution to the article: research and scientific writing of the article.

Contribution to the article: research and scientific writing of the article.
****:Ph.D., Associate Professor N1, University of Castilla-La Mancha, 45071, Toledo, Spain ****:Ph.D., Associate Professor N1, University of Castilla-La Mancha, 45071, Toledo, Spain article: research and scientific writing of the article.

*****:Ph.D., Scientific Coordinator of the UICISA: E and Coordinating Professor with agregação of the ESEnfC, 3046-851, Coimbra, Portugal [demar7@gmail.com].@ http:// orcid.org/0000-0003-4506-0421. Contribution to the article: scientific collaboration, particularly in the validation of the instrument.
}

\section{Resumo}

Enquadramento: A diversidade cultural está presente em todas as sociedades. Os enfermeiros devem ser culturalmente competentes para prestar cuidados de qualidade.

Objetivo: Validar a Escala de Atitude em Relação à Imigração na Enfermagem (EAIE) para português e conhecer as atitudes face à imigraçáo dos estudantes do $1^{\circ}$ ano da licenciatura de uma escola de enfermagem de Portugal.

Metodologia: Estudo descritivo, exploratório e analítico, com aplicaçáo da EAIE, traduzida e adaptada culturalmente para a língua portuguesa, composta por 39 items. Participaram no estudo 143 estudantes.

Resultados: Boa consistência interna da escala medida com o $\alpha$ de Cronbach $(0,94)$. Com a análise unifatorial da escala e de cada item em separado identificaram-se diferenças significativas de atitude entre homens e mulheres em 6 itens e entre grupos etários em 2 itens.

Conclusáo: As atitudes de uma parte dos estudantes não mostram um reconhecimento inequívoco dos direitos dos imigrantes aos recursos sociossanitários. Consideramos necessário aprofundar a formação em competência cultural e sobre o Direito Universal à Saúde.

Palavras-chave: attitude; emigrantes e imigrantes; diversidade cultural; enfermagem; saúde 


\section{Introduction}

In the current age of globalization, cultural, ethnic, and linguistic diversity is present in all societies.

In a society with evident cultural diversity, the relevance of attention to such diversity is manifest, and the concept of cultural competence in health systems is becoming a hot topic.

Cultural competence is the capacity of the health system and healthcare professionals to value the sociocultural factors of patients as part of their professional competencies, thus engaging the biopsychosocial approach to health care. It is the congruent adaptation of health care to the patient's culture. Cultural competence is a dynamic process through which the health professional, or a health system, seeks to provide care using strategies based on cultural heritage knowledge, on attitudes and behaviors of whom care is directed at (Giger \& Davidhizar, 2001). One can say that cultural competence assumes itself as a good alternative to reduce inequities in the access and use of health services in culturally diverse social contexts. It is composed of the following elements: sensitivity, knowledge, and skills (Alizadeh \& Chavan, 2015).

The authors assume that, more than cognitive training, an attitude of openness, acceptance, and harmony with culturally different people is crucial, even if they are not understood. Attitude is a basic concept in Social Psychology and is social because one learns it in the process of socialization. Among the different definitions of attitude, the authors consider that of Young \& Flügel:

The tendency or learned predisposition, more or less generalized and of affective tone, to respond rather persistently and distinctly, usually positively or negatively (for or against), to a situation, idea, value, object, or class of material objects, or to a person or group of persons. (1967, p. 9)

In view of the above, this study aims to know the attitudes toward immigration of first-year students of a nursing school in Portugal.

\section{Background}

Cultural competence has been gaining promi- nence among health professionals and health policymakers, as it facilitates the recognition of another person's cultural background, as well as the adaptation of health professionals' attitudes and behaviors to that person (Marzilli, 2014). The effectiveness of programs that apply cultural competence in the care of immigrant patients is well documented (Gil \& Solano, 2017).

In this respect, cultural competence was considered an strategic approach to health care in contexts of cultural diversity, as a process based on group heterogeneity (Perng \& Watson, 2012). This process involves the training of health professionals aiming at improving their cultural sensitivity, which is the first step toward making the care setting a welcoming/ nurturing space for people/patients, in which the relationship is significant for both parties. If the attitude is regarded as a favorable or unfavorable emotional disposition toward a social object, in this case, immigration, as both a mental and behavioral disposition, it is important to know the attitudes that future nurses have toward immigration. Because, in addition to institutional structures and norms, the quality of nursing care is related to the attitude that nurses adopt toward the person, the family, or the group of immigrants for whom they care. Knowing the attitudes of nursing students toward immigration is crucial because of how they influence interpersonal relations and nursing care to foreign patients and families. Since nurses are directly involved in the care of foreign people and their families, educational institutions are responsible for integrating cultural competence in their course programs as one of the skills nursing students should acquire (Jofré \& Sepúlveda, 2017). Several studies conducted in other countries address the origin of cultural competence training of nursing students (Noble, Nuszen, Rom, \& Noble, 2014; Shatell et al., 2013). A research conducted in Portugal, which analyzes the construction of cultural competence in first-year undergraduate nursing students, concludes that training in cross-cultural nursing promotes the acquisition of cultural skills in students, directly impacting on the approach to the promotion of immigrant families' health (Reis \& Madeira, 2016). 


\section{Research questions}

The attitudes towards immigrants differ between male and female nursing students, and of different ages?

\section{Methodology}

This research study follows an empirical-analytical approach oriented toward the translation and cross-cultural adaptation of the Scale of Attitude toward Immigration in Nursing (EAIE in Spanish) into European Portuguese, which has been authorized by the author of the original Spanish scale (Antonín-Martín \& Tomás-Sábado, 2004). The following procedures were carried out to validate the scale: the Pearson test was applied to correlate the EAIE variables and verify the appropriateness of the factorial analysis. The Kaiser-Meyer-Olkin index was verified to confirm this correlation. Cronbach's alpha coef- ficient was calculated to analyze the internal consistency of the EAIE.

\section{Design}

A descriptive, exploratory, and analytical study that aims to evaluate the attitudes of future nurses toward immigration.

\section{Participants}

A total of 143 students (men and women) from the first year of the Undergraduate Degree in Nursing of a Portuguese nursing school participated in the study (Table 1).

The convenience sampling method was used, to compare, in later research, the results of this study in first-year nursing students with those obtained in third-year nursing students in the same institution. Table 1 shows the distribution of the sample by gender and age group. It is important to highlight that the mean age is 18.73 years, and the standard deviation is 3.287 (Min. = 17, Max. = 44).

\section{Table 1}

Participants' distribution by gender (female and male) and age (17;18;19;>20)

\begin{tabular}{|c|c|c|c|c|}
\hline & & & & $T-1$ \\
\hline & & male & female & 10 tal \\
\hline & 17 & 1 & 14 & 15 \\
\hline & 18 & 13 & 76 & 89 \\
\hline Age group & 19 & 4 & 21 & 25 \\
\hline & 20 & 4 & 10 & 14 \\
\hline Total & & 22 & 121 & 143 \\
\hline
\end{tabular}

\section{Study variables}

The study variables collected were sociodemographic variables (gender and age) and the variable attitude toward immigration, assessed with the EAIE.

\section{Instrument}

In order to evaluate the attitude of students, the EAIE, developed and validated by Antonín-Martín and Tomás-Sábado (2004), was used in the Spanish (original) and Portuguese (translated and culturally adapted) versions. The EAIE is a self-administered Likert-type questionnaire consisting of 39 items with Likert type 4-option response, ranging from total agreement to total disagreement, with a score system from four to one or from one to four, depending on the direction of the item, so that the possible total scores range from 39 to 156 , in which higher scores indicate more favorable attitudes towards immigration.

\section{Procedure}

The questionnaires were applied collectively to the students by the teacher in a first-semester class. The students were previously informed that participation was voluntary, and confidentiality was guaranteed. Each student was assigned a code. 
IBM SPSS Statistics version 22.0 was used for data analysis. After the data were entered, the variables with a negative sense were recoded so that, in all, the highest values corresponded to a more positive attitude toward immigrants and the lowest values to a more negative attitude toward immigrants.

Data analysis was based on the following procedures: data qualitative analysis and application of nonparametric tests were chosen since the EAIE variables are ordinary, composed only of four response options, and the sample is small. The Mann-Whitney $U$ test was carried out to verify the existence of significant differences between two independent groups and a nonparametric variable. This test compares the number of times that a value in one sample has a higher order number than that of the other sample.

The Kruskal-Wallis $H$ test was carried out to confirm the existence of significant differences between three or more independent groups and a nonparametric variable. This test also compares the number of times that a value in one of the samples has a higher order number than that of the other samples.

The Bonferroni-Dunn post hoc test was used for multiple comparisons, thus comparing all pairs of samples to see between which independent groups there are statistically significant differences.

The Kolmogorov-Smirnov test was used to assess whether the sample follows a normal distribution.

The $t$-test was used to assess whether students' attitudes toward immigrants, measured by the total score of the EAIE items, differed significantly between male and female students.

ANOVA was applied to confirm whether students' attitudes toward immigrants, as measured by the total score of the EAIE items, differed significantly between students of different age groups.

\section{Ethical considerations}

The conduction of this study was authorized by the nursing school. A favorable report was obtained from the Ethics Committee of the Health Sciences Research Unit: Nursing (UICISA: E) of the Nursing School of Coimbra (Order no. 531/10-2018). Also, informed consent (Annex 3) was obtained for participation.
Confidentiality and data anonymity were guaranteed in the application of the questionnaire (each student was assigned a code).

\section{Results}

The process of translation and cultural adaptation of the EAIE followed the methodology developed by Beaton, Bombardier Guillemi, and Ferraz (2000) was followed. First, it was translated to Portuguese by a native Spanish teacher. Second, the document was revised by a Portuguese-speaking research expert from the Research Unit of the Nursing School of Coimbra (UICISA: E). The third step was the revision by a Portuguese-speaking expert in translation and cultural adaptation. Finally, back-translation into the original language was performed by a Spanish-speaking professional expert in the topic under analysis. The scale with the consensual translation was sent to the authors of the original EAIE (Antonín-Martín \& Tomás-Sábado, 2004).

Correlations between the EAIE variables were assessed using Pearson's correlation coefficient, and the result was low correlations. The Kaiser-Meyer-Olkin index of 0.589 supports this weak correlation, so factor analysis was not considered.

The scale's validation tests resulted in a Cronbach' alpha coefficient of 0.94 and a test-retest coefficient of 0.90 , which confirms the scale's good internal consistency.

The Kolmogorov-Smirnov test revealed that the sample follows a normal distribution $(Z=$ $0.066 ; p=0.200$ ).

The results show that there are no statistically significant differences in the students' attitudes toward immigrants, assessed using the total score of the EAIE items, between men and women (men: $M=120.95 ; S D=10.504$; women: $M$ $=121.83 ; S D=9.829 ; t=-0.381 ; p=0.703)$. It was concluded, with ANOVA's test, that there were no statistically significant differences in the students' attitudes toward immigrants, assessed using the total score of the EAIE items between the different age groups $(F=0.735$; $p=0.533)$.

The questionnaire was analyzed by items that demonstrate both positive and negative attitudes (Table 2). Table 2 shows that the most positive 
attitudes, with percentages of total agreement and agreement higher than $80 \%$, of both men and women, were related to items $3,4,5,14$, $18,19,32,39$; with percentages between $60 \%$ and $80 \%$ of total agreement and agreement of men and women were related to items 20 and 28; and the items with the greatest differences at the level of total agreement or agreement between men and women were items $13(\mathrm{~W}=80.2 \%$, $\mathrm{M}=72.7 \%), 29(\mathrm{~W}=76.9 \%, \mathrm{M}=90.9 \%)$, and 38 (W = 72.7\%, $\mathrm{M}=40.9 \%$ ).

As regards negative attitudes, percentages of total disagreement and disagreement of both men and women were higher than $80 \%$ with respect to items $2,10,22,24,25,30,35,36$,
37 ; percentages between $60 \%$ and $80 \%$ of total disagreement and disagreement between men and women with respect to items $8,11,15$, $16,21,31$; percentages lower than $30 \%$ of total disagreement and disagreement of both men and women with respect to items 7 and 9; and the items with the most differences in total disagreement or disagreement between men and women were items $26(\mathrm{~W}=90.1 \%$, $\mathrm{M}=77.3 \%), 23(\mathrm{~W}=91.5 \%, \mathrm{M}=77.3 \%), 1$ $(\mathrm{W}=48.7 \%, \mathrm{M}=59.1 \%), 12(\mathrm{~W}=45.5 \%, \mathrm{M}$ $=68.2 \%), 17(\mathrm{~W}=55.4 \%, \mathrm{M}=45.5 \%), 27$ $(\mathrm{W}=76 \%, \mathrm{M}=59.1 \%)$, and $34(\mathrm{~W}=77.7 \%$, $\mathrm{M}=54.5 \%)$.

Table 2

Questionnaire "Scale of Attitude toward Immigration in Nursing", first-year students of a Portuguese nursing school

\begin{tabular}{|c|c|c|c|c|}
\hline \multirow{2}{*}{$\begin{array}{ll}\text { Items } \\
\text { Positive attitudes }\end{array}$} & \multicolumn{2}{|c|}{ TA/A* (\%) } & \multicolumn{2}{|c|}{ TD/D* (\%) } \\
\hline & W & $\mathbf{M}$ & W & $\mathbf{M}$ \\
\hline $\begin{array}{l}3 \text { - We must ensure that immigrants can maintain their customs } \\
\text { and cultural patterns. }\end{array}$ & 89.3 & 81.8 & 10.7 & 18.2 \\
\hline 4 - Ethnic diversity enriches our country's culture. & 94.2 & 90.9 & 5.8 & 9.1 \\
\hline $\begin{array}{l}5 \text { - We must make a greater effort to provide immigrants with a } \\
\text { better quality of life. }\end{array}$ & 85.1 & 95.5 & 14.9 & 4.5 \\
\hline $\begin{array}{l}6 \text { - Immigrants, legal and illegal, should have access to health care } \\
\text { and education free of charge. }\end{array}$ & 57 & 63.6 & 43 & 36.4 \\
\hline $\begin{array}{l}13 \text { - We are obligated to respect the culture and customs of } \\
\text { immigrants. }\end{array}$ & 80.2 & 72.7 & 19.8 & 27.3 \\
\hline $\begin{array}{l}14 \text { - An effort must be made to ensure that immigrants are } \\
\text { incorporated into our society as full citizens. }\end{array}$ & 91.7 & 90.5 & 8.3 & 9.5 \\
\hline $\begin{array}{l}18 \text { - We must encourage immigrants to have places of worship } \\
\text { where they can practice their beliefs and religions. }\end{array}$ & 84.3 & 86.4 & 15.7 & 13.6 \\
\hline $\begin{array}{l}19 \text { - The coexistence of diverse cultures favors knowledge and } \\
\text { mutual respect. }\end{array}$ & 95.9 & 100 & 4.1 & 0 \\
\hline $\begin{array}{l}20 \text { - Immigration and the consequent birth rate increase favors } \\
\text { countries with demographic balance difficulties. }\end{array}$ & 71.1 & 72.7 & 28.9 & 27.3 \\
\hline $\begin{array}{l}28 \text { - Children of immigrants, legal or illegal, have the right to free } \\
\text { schooling. }\end{array}$ & 77.7 & 68.2 & 22.3 & 31.8 \\
\hline $\begin{array}{l}29 \text { - All immigrants should enjoy the same working conditions as } \\
\text { natives of the country. }\end{array}$ & 76.9 & 90.9 & 23.1 & 9.1 \\
\hline $\begin{array}{l}32 \text { - All people living in the same country, regardless of their origin } \\
\text { or ethnicity, should have the same rights. }\end{array}$ & 95 & 95.5 & 5 & 4.5 \\
\hline $\begin{array}{l}33 \text { - Actually, we take advantage of immigrants to offer them the } \\
\text { most precarious jobs. }\end{array}$ & 50 & 63.6 & 50 & 36.4 \\
\hline $\begin{array}{l}38 \text { - The state should provide more resources to the integration of } \\
\text { minorities. }\end{array}$ & 72.7 & 40.9 & 27.3 & 59.1 \\
\hline
\end{tabular}




\begin{tabular}{|c|c|c|c|c|}
\hline $\begin{array}{l}39 \text { - It is unfair to associate the phenomenon of immigration with } \\
\text { crime rates rise. }\end{array}$ & 90.1 & 90.9 & 9.9 & 9.1 \\
\hline \multicolumn{5}{|l|}{ Negative attitudes } \\
\hline $\begin{array}{l}1 \text { - The foreigner who commits a crime should be expelled from } \\
\text { the country. }\end{array}$ & 51.3 & 40.9 & 48.7 & 59.1 \\
\hline 2 - The arrival of immigrants has favored an increase in crime rates. & 19.8 & 18.2 & 80.2 & 81.8 \\
\hline $\begin{array}{l}7 \text { - There are groups of immigrants who are unable to integrate } \\
\text { into our society. }\end{array}$ & 78.5 & 72.7 & 21.5 & 27.3 \\
\hline 8 - Cultural diversity leads to a certain loss of our indigenous values & 22.5 & 22.7 & 77.5 & 77.3 \\
\hline $\begin{array}{l}9 \text { - In some cases, immigrants receive more social benefits than } \\
\text { native people. }\end{array}$ & 83.5 & 77.3 & 16.5 & 22.7 \\
\hline 10 - Immigrants, in general, are careless with their body hygiene. & 5.8 & 13.6 & 94.2 & 86.4 \\
\hline 11 - Many immigrants are not respectful of human rights & 33.1 & 31.8 & 66.9 & 68.2 \\
\hline $\begin{array}{l}12 \text { - Many immigrants take advantage of the health and social } \\
\text { resources achieved through many years of effort. }\end{array}$ & 54.5 & 31.8 & 45.5 & 68.2 \\
\hline 15 - In general, immigrants do very little to integrate into our society. & 28.9 & 22.7 & 71.1 & 77.3 \\
\hline 16 - Immigrants occupy jobs that leave many of us unemployed. & 35.5 & 36.4 & 64.5 & 63.6 \\
\hline 17 - Immigrants must adapt to the customs of our country. & 44.6 & 54.5 & 55.4 & 45.5 \\
\hline 21 - Illegal immigrants should not have access to public health. & 25.8 & 31.8 & 74.2 & 68.2 \\
\hline $\begin{array}{l}22 \text { - Occasionally, certain acts of violence against immigrants may } \\
\text { be justified. }\end{array}$ & 5 & 4.5 & 95 & 95.5 \\
\hline $\begin{array}{l}23 \text { - To a large extent, the collapse of public health is caused by } \\
\text { increased immigration. }\end{array}$ & 8.5 & 22.7 & 91.5 & 77.3 \\
\hline 24 - Too many resources are focused on immigration care. & 6.7 & 9.1 & 93.3 & 90.9 \\
\hline $\begin{array}{l}25 \text { - An European citizen living in Spain brings more benefits to } \\
\text { our society than an African, Asian, or South American immigrant. }\end{array}$ & 10.1 & 4.5 & 89.9 & 95.5 \\
\hline 26 - Immigrants and gypsies hinder the country's development. & 9.9 & 22.7 & 90.1 & 77.3 \\
\hline 27 - Immigrants do not integrate because they do not want to. & 24 & 40.9 & 76 & 59.1 \\
\hline $\begin{array}{l}30 \text { - If this situation continues, the customs and beliefs of } \\
\text { immigrants will prevail in our society in the medium term. }\end{array}$ & 17.5 & 18.2 & 82.5 & 81.8 \\
\hline 31 - Ethnic minorities are a source of social conflict. & 37.5 & 40.9 & 62.5 & 59.1 \\
\hline $\begin{array}{l}34 \text { - The massive influx of immigrants will cause in the medium } \\
\text { term serious health and social problems. }\end{array}$ & 22.3 & 45.5 & 77.7 & 54.5 \\
\hline $\begin{array}{l}35 \text { - If I have a choice, I prefer not to sit next to an immigrant on } \\
\text { public transportation. }\end{array}$ & 0 & 0 & 100 & 100 \\
\hline 36 - In general, I can not stand the North Africans. & 0 & 0 & 100 & 100 \\
\hline 37 - I fear for my safety when I see a group of North Africans. & 2.5 & 13.6 & 97.5 & 86.4 \\
\hline
\end{tabular}

Note. $\mathrm{W}=$ Women $; \mathrm{M}=\mathrm{Men} ; \mathrm{TA} / \mathrm{A}=$ Totally Agree/Agree; $\mathrm{TD} / \mathrm{D}^{*}=$ Totally Disagree/Disagree. 
The independent gender and age variables were considered to confirm the existence of significant differences between men and women, and between age groups concerning the attitudes (EAIE). The level of agreement or disagreement was compared concerning the items that make up the scale, between male and female students, using the Mann-Whitney $U$ test.

Table 3 shows that there are statistically significant differences between the level of agreement with items 3, 12, 19, 27, 29, and 38, between students. The level of agreement with the expression "We must ensure that immigrants can maintain their customs and cultural patterns" is significantly higher in women $(\mathrm{W}=3.39)$ than in men $(\mathrm{M}$ $=3.05 ; U=941 ; p=0.016$ ).

The level of disagreement with the expression "Many immigrants take advantage of the health and social resources achieved through many years of effort" is significantly higher in men $(\mathrm{M}=2.86)$ than in women $(\mathrm{W}=2.44 ; U=$
$965 ; p=0.029)$.

The level of agreement with the expression "The coexistence of diverse cultures favours knowledge and mutual respect" is significantly higher in women $(\mathrm{W}=3.74)$ than in men $(\mathrm{M}$ $=3.55 ; U=1037 ; p=0.029)$.

The level of disagreement with the expression "Immigrants do not integrate because they do not want to" is significantly higher in women $(\mathrm{W}=2.98)$ than in men $(\mathrm{M}=2.59$; $U=995.5$; $p=0.040)$.

The level of agreement with the expression "All immigrants should enjoy the same working conditions as natives of the country" is significantly higher in men $(M=3.64)$ than in women $(\mathrm{W}=3.13 ; U=912 ; p=0.011)$.

The level of agreement with the expression "The state should provide more resources to the integration of minorities" is significantly higher in women $(\mathrm{W}=2.92)$ than in men $(\mathrm{M}$ $=2.45 ; U=911 ; p=0.012)$.

Table 3

Assessment of the existence of statistically significant differences between students about the EAIE, using the Mann-Whitney U test.

\begin{tabular}{|c|c|c|c|}
\hline \multirow[b]{3}{*}{ Items } & \multicolumn{2}{|c|}{ Gender } & \multirow{3}{*}{$\begin{array}{c}\text { Mann-Whitney } U \\
\text { test; sig. }\end{array}$} \\
\hline & Women & Men & \\
\hline & $\begin{array}{l}\text { Mean; Standard } \\
\text { Deviation; Median } \\
(M \pm S D / \mathrm{Me})\end{array}$ & $\begin{array}{l}\text { Mean; Standard } \\
\text { Deviation; Median } \\
(M \pm S D / \mathrm{Me})\end{array}$ & \\
\hline $\begin{array}{l}3 \text { - We must ensure that immigrants } \\
\text { are able to maintain their customs and } \\
\text { cultural patterns. }\end{array}$ & $3.39 \pm 0.746 / 4$ & $3.05 \pm 0.653 / 3$ & $\begin{array}{l}U=941 \\
p=0.016\end{array}$ \\
\hline $\begin{array}{l}12 \text { - Many immigrants take advantage } \\
\text { of the health and social resources gained } \\
\text { through many years of effort. }\end{array}$ & $2.44 \pm 0.826 / 2$ & $2.86 \pm 0.834 / 3$ & $\begin{array}{l}U=965 \\
p=0.029\end{array}$ \\
\hline $\begin{array}{l}19 \text { - The coexistence of diverse cultures } \\
\text { favors knowledge and mutual respect. }\end{array}$ & $3.74 \pm 0.559 / 4$ & $3.55 \pm 0.510 / 4$ & $\begin{array}{l}U=1037 \\
p=0.029\end{array}$ \\
\hline $\begin{array}{l}27 \text { - Immigrants do not integrate because } \\
\text { they do not want to. }\end{array}$ & $2.98 \pm 0.724 / 3$ & $2.59 \pm 0.796 / 3$ & $\begin{array}{l}U=995,5 ; \\
p=0.040\end{array}$ \\
\hline $\begin{array}{l}29 \text { - All immigrants should enjoy the } \\
\text { same working conditions as natives of } \\
\text { the country. }\end{array}$ & $3.13 \pm 0.921 / 3$ & $3.64 \pm 0.658 / 4$ & $\begin{array}{l}U=912 \\
p=0.011\end{array}$ \\
\hline $\begin{array}{l}38 \text { - The State should provide more } \\
\text { resources to the integration of minorities. }\end{array}$ & $2.92 \pm 0.770 / 3$ & $2.45 \pm 0.858 / 2$ & $\begin{array}{l}U=911 \\
p=0.012\end{array}$ \\
\hline
\end{tabular}

Note. $M=$ Mean; $S D=$ Standard Deviation; $M e=$ Median. 
The level of agreement or disagreement regarding the items that make up the scale was compared among students with $17,18,19$, or over 20 years of age, using the Kruskal-Wallis $H$ test.

It was confirmed that there are significant differences (Table 4) in the levels of agreement between students with $17,18,19$, or more than 20 years of age, in items 11 and 22 .

After checking for differences, the Bonferroni-Dunn post-hoc test was used to assess which age pairs had such differences.
In the item "Many immigrants are not respectful of human rights", there were statistically significant differences in the levels of agreement between 20-year-olds or older and 17-year-olds $(p=0.008)$, and also between 20 -year-olds or older and 18-year-olds $(p=0.001)$.

The Bonferroni-Dunn post-hoc test revealed no statistically significant differences in the levels of agreement with the item "Occasionally, certain acts of violence against immigrants may be justified" between age pairs.

Table 4

Assessment of the existence of statistically significant differences between students of different age groups regarding the EAIE, using the Kruskal-Wallis $\mathrm{H}$ test

\begin{tabular}{|c|c|c|c|c|c|c|}
\hline \multirow{2}{*}{ Items } & 17 & 18 & 19 & $>=20$ & \multirow{2}{*}{$\begin{array}{l}\text { Kruskal- } \\
\text {-Wallis } H\end{array}$} & \multirow{2}{*}{$\begin{array}{l}\text { Bonferroni- } \\
\text {-Dunn }\end{array}$} \\
\hline & $M \pm S D$ & $M \pm S D$ & $M \pm S D$ & $M \pm S D$ & & \\
\hline $\begin{array}{l}11 \text { - Many immigrants are } \\
\text { not respectful of human } \\
\text { rights. }\end{array}$ & $\begin{array}{l}3.13 \pm \\
0.640\end{array}$ & $3 \pm 0.905$ & $\begin{array}{c}2.76 \pm \\
1.012\end{array}$ & $2 \pm 0.679$ & $\begin{array}{c}\mathrm{H}=15.562 \\
p=0.001\end{array}$ & $\begin{array}{c}20-18-42.854 ; \\
p=0,001 \\
20-17-47.193 ; \\
p=0.008\end{array}$ \\
\hline $\begin{array}{l}22 \text { - Ocasionally, certain } \\
\text { acts of violence against im- } \\
\text { migrants may be justified. }\end{array}$ & $4 \pm 0$ & $\begin{array}{l}3.65 \pm \\
0.644\end{array}$ & $\begin{array}{c}3.80 \pm \\
0.500\end{array}$ & $\begin{array}{l}3.93 \pm \\
0.267\end{array}$ & $\begin{aligned} \mathrm{H} & =8.196 ; \\
p & =0.042\end{aligned}$ & - \\
\hline
\end{tabular}

Note. $M=$ Mean; $S D=$ Standard Deviation.

\section{Discussion}

At first, the results of most analyzed items show that there are no statistically significant differences in attitudes toward immigration between the men and women who participated in this study and between age groups.

Thus, it appears that the gender variable, as a rule, is not a determining factor for attitudes toward immigration. This finding differs from that of a study conducted by Grueso and Arroyo (2016) in students of the University of Córdoba, in Spain, in which women showed a better attitude toward immigrants than men. However, about half of the students disagreed with some of the items, for example, $6,33,38$, 1,12 , and 17 , reflecting the lack of unequivocally positive attitudes toward immigrants. Nevertheless, the results of this study concur with those of the European Social Survey (2016) and differ from the study Opinions and attitudes of the Andalusian population toward immigration (Observatorio Permanente Andaluz de las Migraciones, 2017). The study states that, although the results are very similar between men and women in this edition, the evaluation by women in previous surveys (since 2005) has always been more negative than by men.

According to the latest report from the European Commission (Comisión Europea, 2017), based on interviews carried out in October 2017 in all European Union (EU) member states, $79 \%$ of Portuguese people are supportive of the personal and professional interaction with immigrants.

This information is relevant to this study because, as stated by Roca and Vega (2007), the notion of a specific group nurtured by society reflects on nursing students.

However, a more detailed analysis of this study's results shows that there are differences between the attitudes of men and women in certain items of the scale (EAIE). The female participants in this study agree that efforts should be 
made so that immigrants can maintain their customs and cultural patterns and that the coexistence between different cultures favors knowledge and mutual respect. This opinion mirrors that manifested by the healthcare professionals of the Melilla Regional Hospital in a research study that used this scale (EAIE), (Sánchez Ojeda, Alemany, \& Gallardo, 2017). On the other hand, and although the female participants believe that the State should ensure the integration of minorities, they blame immigrants for any difficulties occurred in the process since they consider that immigrants do not integrate because they do not want to. The study conducted by García (2015) with nursing students in Huelva, Spain, achieved this same result.

However, this result does not concur with those of the European Commission (Comisión Europea, 2017), in which Portugal is described as the second country of the European Union whose perception of immigrant integration is more positive and, therefore, exceeds the European average set at $54 \%$ with $77 \%$ of Portuguese people considering that immigrant integration is satisfactory and a two-way process. Eighty-three percent feel that inclusion is a shared responsibility between the host society (the Portuguese society, in this case) and foreign people.

In this respect, it would be relevant to analyze the meaning of integration. Perhaps the underlying purpose of this approach comes from one of the models of immigrant integration into a new society, the assimilationist model. This model constitutes a supposed cultural standardization, in which minorities will adopt the language, the values, and the signs of identity of the majority culture and, at the same time, will forsake theirs (Ugarte, 2015).

This model has been strongly criticized and, for various reasons, is based on the premise that all societies are internally homogeneous, which is not true. It presents a static view of culture and drops all responsibility for the integration in the hands of the immigrant population.

Concerning to the results of this study, it is evident that these ideas contradict their perception of the rights of immigrants, who are not considered first-class citizens because people do not recognize their right to enjoy the same working conditions as native people and blame them for an abuse of the health and social resources of the host country, Portugal. The same results occur in the study above by García (2015). The age variable analysis revealed a significant difference regarding their perception of respect for human rights by the majority of immigrants. The youngest students, less than 20 years old, believe that many immigrants do not respect human rights, while 20-year-olds or older think the opposite.

\section{Conclusion}

As the current social context has great cultural diversity, and nursing care is developed with individuals and groups of individuals of that context, nursing care must be culturally competent.

Considering attitude to be one of the elements which influence behaviors directly, in the case of nursing care, attitude precedes the interpersonal relationship that occurs between nurse and patient.

In this study, it is essential to know the idea deeply behind the concept of "integration" when focusing on the care relationship, the objectives regarding the immigrant population, whether there is an attitude of intercultural dialogue or not. These opinions and attitudes have a direct consequence in the future nurse-patient relationship.

It is worrisome that there is a part of the students who do not fully recognize the rights of immigrants and consider them minor citizens who should not have all social and health benefits. This stance is far from an attitude that defends the universal right to health and a commitment to a society based on social justice.

Hence, there is a need for training in cultural competence for nursing professionals.

Training development should also focus on Human Rights, specifically the Universal Right to Health. From this perspective, all people have the same rights, regardless of their country of origin.

According to the premise that cultures change over time, a limitation of this research is that data were collected in a specific period, and attitudes can vary at any time.

The collected sample is small for the factor analysis, factor analysis should only be carried out when there is at least a sample of five subjects per variable. 


\section{References}

Alizadeh, S., \& Chavan, M. (2015). Cultural competence dimensions and outcomes: A systematic review of the literature. Health and Social Care in the Community, 4(6), 117-130. doi:10.1111/hsc.12293

Antonín-Martín, M., \& Tomás-Sábado, J. (2004). La escala de actitud ante la inmigración para enfermería: Validación preliminar. Enfermería Científica, 262-263, 77-82. Retrieved from https://www.researchgate.net/publication/262727094_La_escala_de_actitud_ante_la_inmigracion_para_enfermeria_Validacion_preliminar

Beaton, D. E., Bombardier, C., Guillemin, F., \& Ferraz, M. B. (2000). Guidelines for the process of cross-cultural adaptation of self-report measures. Spine, 25(24), 31863191. Retrieved from https://lab.research.sickkids.ca/ pscoreprogram/wp-content/uploads/sites/72/2017/12/ Beaton2000-GuidelinesCrossCulturalAdaptation.pdf

Comisión Europea. (2017). Eurobarómetro standard 88: Informe nacional: Opinión pública en la unión europeia. Retrieved from https:/ec.europa.eu/spain/sites/spain/ files/eb88_nat_es_es.pdf

García, E. B. (2015). Competencia cultural en salud: Conocimientos, prácticas y actitudes ante los cuidados culturales (Ph.D. Thesis). Available at http://hdl.handle. net/10272/11441

Giger, J. N., \& Davidhizar, R. (2001). The giger and davidhizar transcultural assessment model. Journal of Transcultural Nursing, 13(3), 185-188. doi:10.1177/10459602013003004

Gil, M. D., \& Solano, M. C. (2017). La aplicación del modelo de competencia cultural en la experiencia del cuidado en profesionales de enfermería de atención primaria. Atención Primaria, 49(9), 549-556. doi:10.1016/j.aprim.2016.10.013

Grueso, F. J., \& Arroyo. L. M. (2016). La actitud de los estudiantes de enfermería de la UCO hacia el paciente inmigrante. Ciber Revista, 49, 43-55. Retrieved from http://www.enfermeriadeurgencias.com/ciber/ mayo2016/pagina8.html

Jofré, S., \& Sepúlveda, C. (2017). Migración en Chile: Nuevo desafío para la formación de competencias culturales en estudiantes de enfermería. Enfermería Actual de Costa Rica, 33, 88-98. doi:10.15517/revenf. v0i33.28950

Marzilli, C. (2014). Concept analysis of culture applied to nursing. Creative Nursing, 20(4), 227-233.

Noble, A., Nuszen, E., Rom, M., \& Noble, L. M. (2014). The effect of a cultural competence educational intervention for first-year nursing students in Israel. Journal of Transcultural Nursing, 25(1), 87-94. doi:10.1177/1043659613503881

Observatorio Permanente Andaluz de las Migraciones. (2017). Opiniones y actitudes de la población andaluza ante la inmigración. Retrieved from http://www. juntadeandalucia.es/justiciaeinterior/opam/sites/default/files/DOC/Informe_final_OPIA_publicaci\%C3\%B3n_1.pdf

Perng, S. J., \& Watson, R. (2012). Construct validation of the nurse cultural competence scale: A hierarchy of abilities. Journal Clinical Nursing, 21(11-12), 16781684. doi:10.1111/j.1365-2702.2011.03933.x

Reis, A., \& Madeira, A. (2016). Saúde das famílias imigrantes: Estratégias pedagógicas na formação em enfermagem. Revista Millenium, 2(1), 63-69. Retrieved from https://repositorio.ipsantarem.pt/ bitstream/10400.15/1979/1/Revista\%20Millenium-2016_2\%281\%29_Pags.\%2063-69.pdf

Roca, N., \& Vega, C. (2007). Diversidad cultural: Actitudes, valores by saberes de los estudiantes de enfermería. EMIGRA, Educació, Migracions i Infáncia, 73, 1-19. Retrieved from https://dd.uab.cat/pub/emigrawp/ emigrawp_a2007n73/emigrawp_a2007n73p1.pdf

Sánchez-Ojeda, M. A., Alemany, I., \& Gallardo, M. A. (2017). The nursing department's view towards moroccan patients. Revista Escola de Enfermagem da USP, 51, e03227. doi:10.1590/S1980-220X2016022703227

Shattell, M. M., Nemitz, E. A., Crosson, N. P., Zackeru, A. R., Starr, S., \& Gonzales, C. (2013). Culturally competent practice in a pre-licensure baccalaureate nursing program in the United States: A mixed-methods study. Nursing Education Perspectives, 34(6), 383-389. Retrieved from https://pdfs.semanticscholar.org/75e 4/ 47f690cbb2e21b05a819a512b38faf179958.pdf

Ugarte, M. I. (2015). La salud reproductiva de las mujeres inmigrantes marroquies: Análisis cualitativo de las representaciones sociales de mujeres y profesionales de la salud (Ph.D. Thesis). Universidad de Castilla-La Mancha, Espanã. Retrieved from http://hdl.handle. net/10578/9051

Young, K., \& Flügel, J. C. (1967). Psicología de las actitudes. Buenos Aires, Argentina: Paidos. 